\title{
THE COMPETING JURISDICTIONS OF INTERNATIONAL COURTS AND TRIBUNALS (WROCLAW, 13-14 APRIL 2011)
}

\author{
BARTLOMIEJ KRZAN*
}

On 13-14 April 2011, the Department of International and European Law of the Faculty of Law, Administration and Economics at the University of Wrocław organized together with the International Law Association (Polish Branch) an international seminar on the Competing Jurisdictions of International Courts and Tribunals.

The ongoing proliferation of international courts and tribunals has provoked effects at least twofold. The increasing number of dispute settlement mechanisms may lead to a conflict of jurisdictions. Under international law it is difficult to exclude such a scenario. In addition to their possible overlapping jurisdictions, the international courts and tribunals may differ in terms of jurisprudence. Both of these problems are of crucial importance not only for the sake of the debate on the fragmentation in international law. It thus came as no surprise, that the topic of the seminar attracted the attention of scholars from various universities as well as numerous staff members and students of the Faculty of Law, Administration and Economics.

The seminar was opened by Dean Włodzimierz Gromski, who welcomed the guests and participants. The first session was chaired by Professor Dagmara Kornobis-Romanowska.

The floor was first given to James Crawford, Whewell Professor of International Law at the University of Cambridge. After giving a general introduction to the problem Professor Crawford concentrated on the jurisdictional competition between the International Court of Justice and the International Tribunal for the Law of the Sea. His speech was filled with a variety of practical insights, as the author drew extensively on his rich experience in adjudicating and counseling in those two judicial institutions.

The second paper was delivered by Professor Pavel Šturma of the Charles University, Prague. In his contribution Professor Šturma clarified

DOI: 10.2478/wrlae-2013-0043

${ }^{*} \mathrm{PhD}$, Assistant Professor; Department of International and European Law; Faculty of Law, Administration and Economics; Wroclaw University; bakr@prawo.uni.wroc.pl 
differing concepts of competing jurisdictions and commented on the issue of human rights protection from the perspective of international arbitration.

The third speaker was Dr. Joanna Gomula, a Fellow at the Lauterpacht Centre for International Law at the University of Cambridge. Given her expertise in the law of the World Trade Organization, Dr. Gomula's paper concentrated on the conflicting jurisdictions in WTO jurisprudence and illustrated the matter with some case-law of practical importance.

The second session was chaired by Professor James Crawford and was partly devoted to the competing jurisdictions of both international and domestic courts. The first speech was delivered by Professor Anna Wyrozumska of the University of Łódź, the President of the Polish Branch of the International Law Association, who considered the competing jurisdictions drawing on the jurisprudence of national courts and the European Court for Human Rights on state immunity.

The next speaker was Professor Michael Geistlinger of the Paris Lodron University, Salzburg. Drawing on his experience as an arbitrator at the Court of Arbitration for Sport in Lausanne, Professor Geistlinger shed some different light on the interaction between international and domestic jurisdictions from the perspective of sports arbitration.

In the final contribution Dr. Bartłomiej Krzan of the University of Wrocław analysed the parallel operation of the International Criminal Court and the International Court of Justice. While arguing the low probability of these Courts acting as competitors, the author identified the most common areas of divergence in their jurisprudence and suggested methods to overcome the clash.

The papers delivered during both sessions provoked very lively and stimulating discussions that went far beyond the expected time-limit. Doctrinal views were confronted with the practice of international courts. The deliberations were continued during lunch.

The organizers would like to express their gratitude for the financial support in organizing a seminar to the Authorities of the Faculty of Law, Administration and Economics, and to the Municipality of Wrocław, since the visit of Professor Crawford was financed from the Visiting Professors Program of the Scientiae Wratislavienses Fund. A special thank you is due to a number of $\mathrm{PhD}$ students at the Department of International and European Law who helped with the seminar preparation. 